\title{
Assessing the abilities of receiving refugees based on the Fuzzy AHP model
}

\author{
Xi Gao* \\ School of mechanical design, the North China Electric Power University, Baoding 071000, China; \\ 454413105@qq.com
}

\begin{abstract}
More than a million migrants and refugees crossed into Europe in 2015, sparking a crisis as countries struggle to cope with the influx. When it comes to refugee crises, comprehensive national strength should be regarded as the most important factor. The stronger the comprehensive national strength of EU is, the more refugees they can accept. Accordingly, the crisis can be reduced. Therefore, to measure a refugee crisis, refugee acceptance index is proposed in this paper. Factors, like the safety of six travel routes, and a specific country's GDP, population density, are integrated in the evaluation system. With Fuzzy Analytic Hierarchy Process applied to our model, each country's refugee acceptance index can be exactly calculated and thus assessed.
\end{abstract}

Keywords: refugee crises, Fuzzy AHP model

\section{Introduction}

As is well acknowledged, the refugee crisis is still a tough problem for European countries to solve. To begin with, after consulting plenty of literature, we establish factors which may impact the route of the refugees fleeing.

\section{Metrics of refugee crises}

\subsection{The selection of parameters of refugees}

When it comes to the possibility of accepting a large number of refugees, the resources of a country are considered to be the primary factor. These include GDP and per capital GDP, the total population and density of population, growth rate of population, unemployment rate and social security rate. Detailed reasons and parameters setting are as follows. 
Table 1 Detailed reasons and parameters

\begin{tabular}{clc}
\hline Evaluation Index & \multicolumn{1}{c}{ The Reason of Selecting it } & $\begin{array}{c}\text { Symbols Used } \\
\text { to Represent } \\
\text { Indexes }\end{array}$ \\
\hline GDP & $\begin{array}{l}\text { GDP is used to measure a country's } \\
\text { comprehensive national strength. }\end{array}$ & $A G_{\text {effect }}$ \\
\hline Per Capital GDP & $\begin{array}{l}\text { The average production can decrease the } \\
\text { limitations of GDP in the later calculation. }\end{array}$ & $G_{\text {effect }}$ \\
\hline The Total Population & $\begin{array}{l}\text { Accepting migrants can coordinate the } \\
\text { issues of population distribution. }\end{array}$ & $P_{\text {effect }}$ \\
\hline Population Density & $\begin{array}{l}\text { It is of great importance that there are } \\
\text { enough places used for refugees' residence. }\end{array}$ & $P D_{\text {effect }}$ \\
\hline Growth Rate of & $\begin{array}{l}\text { In order to slow down the trend of } \\
\text { population aging, they may need to accept } \\
\text { more immigrants. }\end{array}$ & $P I_{\text {effect }}$ \\
\hline Unemployment Rate & $\begin{array}{l}\text { Countries with high unemployment rate are } \\
\text { less willing to accept refugees, because the } \\
\text { arrival of refugees will increase this trend. }\end{array}$ & $U_{\text {effect }}$ \\
\hline Social Security Rate & $\begin{array}{l}\text { The social security system equals to the } \\
\text { social relief system, and refugees prefer to } \\
\text { choose those with high social security rate. }\end{array}$ & In $_{\text {effect }}$ \\
\hline
\end{tabular}

Taking these factors into considerations, we can be establish a refugees acceptance index, Dis_Ind is defined by us as the number of refugees accepted by each country .

And then we are able to deduce the following expression:

$$
\text { Dis_Ind }=w_{1} G_{\text {effect }}+w_{2} P_{\text {effect }}+w_{3} P D_{\text {effect }}+w_{4} A G_{\text {effect }}+w_{5} P I_{\text {effect }}+w_{6} U n_{\text {effect }}+w_{7} I n_{\text {effect }}
$$

In this expression, $w_{i}(i=1,2, . ., 6)$ means the index weight in refugees acceptance index. In addition, the weight vector is $W=\left\{w_{1}, w_{2}, w_{3}, w_{4}, w_{5}, w_{6}\right\}$

\subsection{Fuzzy AHP model}

To analyze these factors associated with such an activity, we use the fuzzy analytic hierarchy process (AHP) to determine each parameter weight. On the other hand, this method is able to decrease the influence of subjective factors in the modeling process.

AHP is proposed by T. L. Saaty [1] for the first time, combining qualitative analysis with quantitative calculation, which is a multiple objective decision-making model. Compared with the AHP model, the fuzzy AHP model has advantages over the consistency test of judgment matrix, a lack of science, the impact of subjective factors when constructing judgment matrix.

\subsubsection{Establishing the fuzzy hierarchical analysis model}

Step 1: Creating a judgment matrix

It is an order matrix created by giving priority to different ones according to certain standards. Assuming that there is a set $\mathrm{Ai}=\{\mathrm{A} 1, \mathrm{~A} 2, \ldots, \mathrm{An}\}$ about some schemes, which has relative importance to a certain criterion. Based on a certain standard rule, each scheme included in Ai is compared with others. And the relative importance is defined as $a_{i j}(i=1,2, \ldots, n)$ so that the judgment matrix $A=\left(a_{i j}\right)_{n \times n}$ can be established. 
Table 2 1-9 scale quoted by T .L .Saaty[ 1]

\begin{tabular}{|c|c|c|}
\hline Scale & Definition & Meaning \\
\hline 1 & Equally important & $\begin{array}{l}\text { Certain attributes of two schemes are } \\
\text { equally important. }\end{array}$ \\
\hline 3 & Weakly Important & $\begin{array}{l}\text { A certain attribute of a scheme is more } \\
\text { important than the other's slightly. }\end{array}$ \\
\hline 5 & Obviously important & $\begin{array}{l}\text { A certain attribute of a scheme is more } \\
\text { important than the other's obviously. }\end{array}$ \\
\hline 7 & Strongly important & $\begin{array}{l}\text { A certain attribute of a scheme is more } \\
\text { important than the other's strongly. }\end{array}$ \\
\hline 9 & Absolutely important & $\begin{array}{l}\text { A certain attribute of a scheme is more } \\
\text { important than the other's absolutely. }\end{array}$ \\
\hline $2,4,6,8$ & $\begin{array}{l}\text { The average value of } \\
\text { adjacent scales }\end{array}$ & Compromise between two adjacent scale \\
\hline $\begin{array}{l}\text { Reciprocal of } \\
\text { scales above }\end{array}$ & Adverse comparison & $\begin{array}{l}a_{i j} \text { means the scale between } A_{i} \text { and } A_{j} \text {, } \\
\text { while } 1 / a_{i j} \text { means the scale between } A_{j} \\
\text { and } A_{i} \text {. }\end{array}$ \\
\hline
\end{tabular}

Step 2: Changing the judgment matrix into a fuzzy judgment matrix

In this part, a new scale can be generated via the following rules.

Get $\alpha \geq 81$ and let $r_{i j}(\alpha)=\log _{a} a_{i j}+0.5$,then we get the fuzzy judgment matrix $R=\left(r_{i j}(\alpha)\right)_{n \times n}$. Obviously, $0 \leq r_{i j}(\alpha) \leq 1, r_{i i}(\alpha)=0.5$ and $r_{i j}(\alpha)+r_{j i}(\alpha)=1$.

The reason why we choose $\alpha \geq 81$ is to make sure that $0 \leq r_{\mathrm{ji}}(\alpha) \leq 1$.

Table 3 the meaning of every fuzzy scale

\begin{tabular}{cll}
\hline Scale & \multicolumn{1}{c}{ Definition } & \multicolumn{1}{c}{ Meaning } \\
\hline 0.5 & equally important & $\begin{array}{l}\text { Certain attributes of two schemes are } \\
\text { equally important. }\end{array}$ \\
\hline $\log _{\alpha} 3+0.5$ & Weakly important & $\begin{array}{l}\text { A certain attribute of a scheme is more } \\
\text { important than the other's slightly. }\end{array}$ \\
\hline $\log _{\alpha} 5+0.5$ & Obviously important & $\begin{array}{l}\text { A certain attribute of a scheme is more } \\
\text { important than the other's obviously. }\end{array}$ \\
\hline $\log _{\alpha} 7+0.5$ & Strongly important & $\begin{array}{l}\text { A certain attribute of a scheme is more } \\
\text { important than the other's strongly. }\end{array}$ \\
\hline $\log _{\alpha} 9+0.5$ & Absolutely important & $\begin{array}{l}\text { A certain attribute of a scheme is more } \\
\text { important than the other's absolutely. }\end{array}$ \\
\hline $\log _{\alpha} i+0.5$, & The average value of & $\begin{array}{l}\text { Compromise between two adjacent } \\
\text { scale }\end{array}$ \\
\hline $\begin{array}{c}\text { a } 2,4,6,8 \\
\text { Reciprocal of }\end{array}$ & Complementation scales & $\begin{array}{l}\mathrm{r}_{\mathrm{ij}} \text { means scale between } \mathrm{A}_{\mathrm{i}} \text { and } \mathrm{A}_{\mathrm{j}}, \\
\text { while 1- } \mathrm{r}_{\mathrm{ij}} \text { means the scale between } \\
\text { Aj and Ai. }\end{array}$ \\
\hline
\end{tabular}

Step 3: Determining the weight of each parameter

The expression of the index weight is

$$
W_{i}=\beta^{\frac{1}{n} \sum_{j=1}^{n} r_{i j}} / \sum_{k=1}^{n} \beta^{\frac{1}{n} \sum_{j=1}^{n} r_{k j}}, i=1,2, \ldots n
$$


The weight vector of fuzzy judgment matrix $R_{i j}=\left(r_{i j}\right)_{n \times n}$ is

$$
W=\left\{\left(w_{1}(\beta), w_{2}(\beta), \ldots, w_{n}(\beta)\right)^{T} \mid w_{i}(\beta)=\beta^{\frac{1}{n} \sum_{j=1}^{n} r_{i j}} / \sum_{k=1}^{n} \beta^{\frac{1}{n} \sum_{j=1}^{n} r_{k_{j}}}, \beta>1, i=1,2 \ldots, n\right\} .
$$

\subsubsection{Solving the fuzzy hierarchical analysis model}

Step 1: Establishing the following comparison matrix according to the importance of various parameters in the model[2].

$$
A_{7 \times 7}=\left[\begin{array}{ccccccc}
1 & 1 & 2 & 2 & 2 & 3 & 3 \\
1 & 1 & 1 & 2 & 2 & 3 & 3 \\
1 / 2 & 1 & 1 & 1 & 1 & 2 & 2 \\
1 / 2 & 1 / 2 & 1 & 1 & 1 & 2 & 2 \\
1 / 2 & 1 / 2 & 1 & 1 & 1 & 2 & 2 \\
1 / 3 & 1 / 3 & 1 / 2 & 1 / 2 & 1 / 2 & 1 & 1 \\
1 / 3 & 1 / 3 & 1 / 2 & 1 / 2 & 1 / 2 & 1 & 1
\end{array}\right]_{7 \times 7}
$$

At the matrix above, $a_{i j}=1 / a_{j i}(i, j=1,2, \ldots 7)$.

Step 2: Changing the conventional comparison matrix into the fuzzy comparison matrix Assume that $\alpha=243$, fuzzy scales at various levels are as follows:

Table 4 The fuzzy scales at various levels

\begin{tabular}{cc}
\hline Scale & Definition \\
\hline 0.5 & equally important \\
0.7 & Weakly Important \\
0.7930 & Obviously important \\
0.8542 & Strongly important \\
0.9 & Absolutely important
\end{tabular}

$0.6262,0.7524,0.8262,0.8786$ The average value of adjacent scales

Reciprocal of scales above Complementation

Meanwhile, matrix A can be transformed to A'

$$
A^{\prime}=\left[\begin{array}{lllllll}
0.500 & 0.500 & 0.626 & 0.700 & 0.752 & 0.793 & 0.826 \\
0.500 & 0.500 & 0.626 & 0.700 & 0.752 & 0.793 & 0.826 \\
0.373 & 0.373 & 0.500 & 0.626 & 0.700 & 0.752 & 0.793 \\
0.300 & 0.300 & 0.373 & 0.500 & 0.626 & 0.700 & 0.752 \\
0.247 & 0.248 & 0.300 & 0.374 & 0.500 & 0.626 & 0.700 \\
0.207 & 0.207 & 0.248 & 0.300 & 0.374 & 0.500 & 0.626 \\
0.173 & 0.173 & 0.207 & 0.248 & 0.300 & 0.374 & 0.500
\end{array}\right]
$$

Step 3: Determining the weight index of each parameter

Let $\beta=e^{10}[3]$, and the result is $W=\{0.3595,0.3595,0.1573,0.0700,0.0316,0.0147,0.0074\}$

Step 4: According to the weight index, we get the expression of refugee distribution below: Dis_Ind $=0.3595 G_{\text {effect }}+0.3595 P_{\text {effect }}+0.1573 P D_{\text {effect }}+0.07 A G_{\text {effect }}+0.0316 P I_{\text {effect }}+0.0147 U n_{\text {effect }}+0.0074 I n_{\text {effect }}$ 


\section{Conclusions}

\section{1 results analysis}

The distribution number of each country given by $\mathrm{EU}$ is adopted to analyze Model 1.And $\mathrm{t}$ he equations are as follows:

$$
\begin{gathered}
q_{c a p, i}=a_{t o t}\left(\alpha_{1} \times \mu_{p o p, i}+\alpha_{2} \times \mu_{G D P, i}+\alpha_{3} \times \mu_{a s, i}+\alpha_{4} \times \mu_{u n, i}\right) \\
\sum_{j=1}^{4} \alpha_{j}=1, \alpha_{1}=\alpha_{2}=0.4, \alpha_{3}=\alpha_{4}=0.1
\end{gathered}
$$

Referring to the standards mentioned above, we can find out that Refugees Acceptance Index completely corresponds with the results above. In the meanwhile, by taking more factors (listed in Section 2.1) into account, we can get more adequate results than EU's, which means this model is reasonable.

\subsection{Sensitivity analysis}

The weakness of traditional AHP is the low passing rate of consistency check, so we change the comparison matrix into fuzzy matrix. Then we use the $\beta$ as the bottom of the weighting function. And the weight of different parameter varies with $\beta$.

\begin{tabular}{cc} 
& Table $5 \quad$ the value of $\beta$ and $W$ \\
\hline Value of $\beta$ & Corresponding of $W$ \\
\hline$e^{5}$ & $W=\{0.2670,0.2670,0.1766,0.1178,0.0791,0.0540,0.0382\}$ \\
$e^{15}$ & $W=\{0.4145,0.4145,0.1200,0.0356,0.0108,0.0034,0.0012\}$ \\
\hline
\end{tabular}

Based on table 4, it's obviously that $W$ changes along with the change of $\beta$. When the value of $\beta$ is small, the gaps between each weight are not obvious. On the contrary, the gaps become obvious when the value of $\beta$ is big. On the one hand, it's flexible to change the weight of data in different parts by setting different value of $\beta$.

\section{References}

[1] Jijun Zhang. Fuzzy analytic hierarchy process (ahp)[J]. Fuzzy sets and systems, $2000,14(2): 80-88$.

[2] Yuejin Lyu. The order of fuzzy hierarchy process based on fuzzy uniform matrix[J]. Fuzzy systems and mathematics, , 2002 , 16 (2) :79-85.

[3] Jibin Lan, Yang Xu, Liangan Huo,etc. Research on the weight of fuzzy analytic hierarchy process[J]. System engineering theory and practicing, 2006 , 26 (9) :107-112. 